Disentangling Contact and Socialization Effects on Outgroup Attitudes in Diverse Friendship Networks

Chloe Bracegirdle ${ }^{1}$, Nils Reimer ${ }^{1}$, Maarten van $Z_{\text {alk }}^{2}$, Miles Hewstone ${ }^{1}$, \& Ralf Wölfer ${ }^{1,3}$

${ }^{1}$ University of Oxford, United Kingdom; ${ }^{2}$ Osnabrück University, Germany; ${ }^{3}$ Deutsches Zentrum für Integrations- und Migrationsforschung, Berlin, Germany

Author Note

We provide all supplemental material in the Online Appendices A-H available at https://osf.io/4n9as/ 


\begin{abstract}
Friendships with members of our own group (ingroup) and other groups (outgroups) shape our attitudes towards outgroups. Research on intergroup contact has shown that the numbers of outgroup and ingroup friends we have influence our outgroup attitudes, while research on socialization has shown that the attitudes held by our friends influence our outgroup attitudes. Past research, however, examined these processes in isolation, which precludes discerning whether having friends, or the attitudes held by our friends, are both important in shaping our outgroup attitudes, and, if so, which is more important. To disentangle these effects, we conducted a five-wave social network study in two ethnically diverse schools $(N=1,170$ students). By applying a novel longitudinal co-evolution model, we were able to separate the effects of having ingroup and outgroup friends (contact effects), and the effects of those friends' attitudes (socialization effects), on individuals' outgroup attitudes, while controlling for friendship selection processes. In so doing, we found that it is principally the attitudes of ingroup friends - not outgroup friends' attitudes or having ingroup and outgroup friends alone - that predict individuals' outgroup attitudes. Our findings have important theoretical implications, as we demonstrate that combining the divergent approaches of intergroup contact and socialization enables us to better understand outgroup attitude development. Our findings also have practical implications, as we show that, even in diverse environments, individuals rely primarily on friends from their own group to inform their attitudes towards other groups.
\end{abstract}

\title{
Keywords:
}

outgroup attitudes, intergroup contact, friendship, socialization, social network analysis 


\section{Disentangling Contact and Socialization Effects on Outgroup Attitudes in Diverse Friendship Networks}

A major challenge for social psychological research is understanding how ethnic prejudice develops in modern societies that are becoming increasingly ethnically diverse (United Nations, 2019; Vertovec, 2007). In diverse societies, individuals are often embedded within correspondingly diverse social networks, and individuals' attitudes towards other ethnic groups develop in these environments (Wölfer \& Hewstone, 2017). Friendships, both with members of a different group (outgroup) and members of the same group (ingroup), could potentially shape outgroup attitudes in two ways. First, individuals' outgroup attitudes may be influenced by the number of friends that they have, especially outgroup friends (Davies et al., 2011), as enshrined in Allport's (1954) 'contact hypothesis', but also ingroup friends (Levin et al., 2003). Second, studies on socialization (Kandel, 1978) show that individuals' outgroup attitudes may be influenced by the attitudes held by their ingroup and outgroup friends (e.g., Van Zalk et al., 2013). The present study uses innovative longitudinal social network analysis to separate and simultaneously examine these effects of ingroup and outgroup friendships on individuals' outgroup attitudes. These effects have not previously been considered together, mainly because of the hitherto insuperable problem of statistically separating the effects. However, new developments in longitudinal social network analysis now enable us to disentangle these effects and thus empirically compare the theoretical predictions from the contact and socialization literatures concerning how friendships shape outgroup attitudes.

\section{How Friends Influence Individuals' Outgroup Attitudes}

In this paper, we distinguish between the effects of the number of friends on individuals' attitudes, hereafter referred to as contact effects (Allport, 1954), and the effects of these 
friends' attitudes on individuals' attitudes, hereafter referred to as socialization effects (Kandel, 1978). This distinction is well established in developmental psychology (Bukowski et al., 1998), but less so in social psychology. Hartup (1996) argued that the implications of friendships cannot be specified without distinguishing between "having friends" (contact effects) and "who friends are" (socialization effects). However, this distinction is rarely considered when examining the effects of friendships on the development of outgroup attitudes.

Moreover, we further separate each effect based on group membership (ethnic ingroup or outgroup), which yields four distinct effects, as shown in Figure 1. Previous research examining the development of outgroup attitudes has studied either contact effects for ingroup and outgroup friends separately (e.g., Levin et al., 2003) or socialization effects for all friends, irrespective of their ethnicity (e.g., Van Zalk et al., 2013). The present study is innovative in simultaneously examining both contact and socialization effects for both ingroup and outgroup friends. In this paper, we contend that disentangling all four effects is essential in order to explore whether and, if so, how friendships shape outgroup attitudes.

\section{Contact Effects:}

Number of ingroup friends (e.g., Number of Asian friends)

Number of outgroup friends (e.g., Number of White friends)

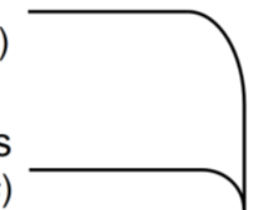

Socialization Effects:<smiles>C=COC1CCCC1OCCOC1CC2CCC21</smiles>

Ingroup friends' outgroup attitudes (e.g., Asian friends' attitudes towards White people)

Outgroup friends' ingroup attitudes (e.g., White friends' attitudes towards White people)
Individuals' outgroup attitudes (e.g., Asian individuals' attitudes towards White people)

Figure 1. An illustration of group-dependent contact and socialization effects. 


\section{Contact Effects}

Intergroup contact theory (Allport, 1954; Brown \& Hewstone, 2005) posits that contact with outgroup members improves attitudes towards the outgroup. An extensive body of research has accumulated providing compelling evidence in support of the theory (Pettigrew \& Tropp, 2006). Meta-analytic evidence suggests that outgroup friendship is an especially powerful form of contact, with stronger positive effects on outgroup attitudes than contact in general (Davies et al., 2011). Outgroup friendship may have a greater effect on outgroup attitudes because friendship occurs over an extended period of time and entails greater active engagement, self-disclosure, intimacy, empathy and trust (MacInnis \& Page-Gould, 2015; Swart et al., 2011b).

Research examining the effects of outgroup friendship on outgroup attitudes typically compares individuals with more outgroup friends to individuals with fewer outgroup friends. Prior studies have relied predominantly on self-report measures of friendship, in which respondents estimate the number or proportion of their friends who are outgroup members (e.g., Swart et al., 2011a). Several recent investigations of intergroup contact theory have instead used a network measure of friendship, in which respondents self-report the specific individuals whom they consider as friends in their social network. Using this measure, studies of friendship networks in European schools have shown that students with more outgroup friends tend to have more positive outgroup attitudes (Munniksma et al., 2013; Wölfer et al., 2016). These studies mark the introduction of social network methodology in socialpsychological research on intergroup contact theory. Social network methodology has, however, long been employed in the wider field of social psychology (e.g., Festinger et al., 1950; Milgram, 1967) and in the sociological study of intergroup friendships (e.g., Joyner \& Kao, 2000). 
Network measures provide robust estimates of outgroup friendship (Wölfer et al., 2015). Social desirability bias can lead individuals to exaggerate the number of outgroup friends they report. Smith (2002) empirically demonstrated a reduction in exaggeration when a network measure of friendship is used, as compared to non-network self-report measures. This improved measurement of outgroup friends is likely to result from differences in reference to group membership: most self-report measures of outgroup friendship reference group membership, while network measures enable respondents to nominate specific individuals as friends without reference to group membership. Furthermore, respondents may more accurately report each specific friend they have than estimate a summary statistic for their number of outgroup friends. Therefore, studies using network measures provide robust evidence for the positive association between outgroup friendship and outgroup attitudes (e.g., Wölfer et al., 2016).

While many studies have investigated the effects of having more outgroup friends on outgroup attitudes, few studies have examined the corresponding effects of having more ingroup friends. Wilder and Thompson (1980) proposed that having more ingroup friends could increase attraction to, identification with, and the salience of norms favoring the ingroup, and thus have negative effects on intergroup relations. Few studies, however, have investigated this claim, and the sparse existing evidence seems to be inconclusive. Levin et al. (2003) found that having more ingroup friends predicted greater ingroup bias (operationalized as the difference in attitudes towards the ingroup and outgroup). In contrast, Munniksma et al. (2015) found no association between the number of ingroup friends and outgroup attitudes. Therefore, further research is required to determine whether having more (as compared to fewer) ingroup friends affects outgroup attitudes.

In summary, ingroup and outgroup friends may have divergent effects on outgroup attitudes. Many studies have shown that having more outgroup friends positively affects 
outgroup attitudes, while the few studies examining the effects of having more ingroup friends have produced mixed results.

\section{Socialization Effects}

Besides the effects of having friends on individuals' attitudes, the influence of those friends' attitudes has largely been neglected in intergroup contact research. Friends may influence individuals' outgroup attitudes so that their attitudes become more similar over time. Kandel (1978) termed this socialization, defined as the increase in similarity between friends over time through mutual influence. Notably, Kandel's definition of socialization, used in the present and prior studies of attitude socialization (e.g., Van Zalk et al., 2013), encompasses only one, albeit a key, aspect of the broader conceptualization of socialization as the process of learning the skills, attitudes and behaviors required to function effectively in a given social context (American Psychological Association, 2020).

Longitudinal social network analysis provides a method for investigating socialization, and research using this method has generated consistent evidence that socialization can shape attitudes towards various groups. Van Zalk et al. (2013) examined the socialization of xenophobic and tolerant attitudes towards immigrants in school friendship networks. They found that friends significantly influenced each other's attitudes over the two-year study so that friends' attitudes became more similar over time. Similar studies of friendship networks have provided evidence for the socialization of anti-immigrant sentiment (Hjerm et al., 2018), homophobic attitudes (la Roi et al., 2020; Poteat, 2007) and attitudes toward ethnic minorities (Zingora et al., 2019).

Each of these studies, however, failed to account for group membership in one or two important ways. Firstly, the studies examined attitudes towards specific ethnic and sexual minority groups, but some samples included participants belonging to these minority groups. 
Accordingly, for majority group participants outgroup attitudes were examined, while for minority group participants ingroup attitudes were examined. Therefore, the studies provide evidence for the general socialization of attitudes towards groups, but not necessarily outgroups in particular. Secondly, the studies did not separate and compare socialization through ingroup and outgroup friends. Instead, friends were considered equal sources of influence, regardless of whether they were ingroup or outgroup friends.

We contend that the socialization of outgroup attitudes is likely to occur primarily through ingroup, not outgroup, friends. Social comparison theory (Festinger, 1954) argues that individuals evaluate their attitudes through comparison with similar others and adjust their attitudes to achieve uniformity within a social group. Similarly, self-categorization theory and its concept of referent informational influence (Turner et al., 1987) propose that individuals conform to the norms of the groups with which they identify, and that only ingroup members provide influential descriptive and prescriptive information. Together, these theories argue that ingroup norms are more important than outgroup norms for shaping attitudes and behaviors.

In support of these theories, research has shown that social influence is stronger when exerted through ingroup than outgroup sources (Abrams et al., 1990). Regarding prejudicial norms, Stangor et al. (2001) found that individuals adjusted their own outgroup attitudes more in accordance with experimental variations of ingroup than outgroup norms. Studies have also demonstrated the effect of ingroup norms on outgroup attitudes in child (McGuire et al., 2015) and adolescent (Thijs \& Verkuyten, 2011) samples. Together, these studies suggest that ingroup norms, rather than outgroup norms, influence individuals' outgroup attitudes. 
In the present study, we explored whether the differential influence of ingroup and outgroup members identified for group-level norms holds for attitude socialization through friends. We predicted that only ingroup friends' attitudes (towards their ethnic outgroup, e.g., for an Asian individual, their Asian friends' attitudes towards White people), and not outgroup friends' attitudes (towards the same target group, their ethnic ingroup, e.g., for an Asian individual, their White friends' attitudes towards White people), would influence individuals' outgroup attitudes. To assess the effect of friends' attitudes on individuals' attitudes, we used social network analysis. We determined the attitudes held by individuals' friends by first identifying the friends each individual nominated in the network, and then directly assessing the friends' self-reported attitudes.

In summary, prior research has provided evidence for attitude socialization through friends, and research on norms suggests that ingroup friends may have a stronger influence than outgroup friends. The present study is theoretically innovative in examining the extent to which outgroup attitude socialization occurs though ingroup friends, outgroup friends, or both, and empirically innovative in its use of a novel longitudinal social network model to examine these issues.

\section{The Present Study}

This study extends previous research by simultaneously examining and contrasting four potential effects of friendships on outgroup attitudes. Specifically, we examine the effects of having ingroup and outgroup friends on individuals' outgroup attitudes (contact effects), and the effects of ingroup and outgroup friends' attitudes on individuals' outgroup attitudes (socialization effects). By simultaneously examining contact and socialization effects we can compare the theoretical predictions from the separate literatures on intergroup contact, on the one hand, and socialization, on the other, to explore how friendships shape outgroup attitudes. 
We build on recent methodological advances by using a novel adaptation of longitudinal social network analysis to disentangle these effects for the first time. Only by analyzing all four effects in conjunction can we assess the unique impact of each. For example, the positive association between outgroup friends and outgroup attitudes, which is well-documented in the intergroup contact literature, may, theoretically, result from contact or socialization effects, or both. Having more outgroup friends may in and of itself improve outgroup attitudes. Alternatively, or additionally, outgroup attitudes may be improved via influence from outgroup friends' more positive attitudes towards their own ingroup.

Based on prior literature, we tested two hypotheses about influences on outgroup attitudes: having more outgroup friends will positively predict individuals' outgroup attitudes over time (Hypothesis 1); and ingroup friends' attitudes will predict individuals' outgroup attitudes such that their attitudes become more similar over time (Hypothesis 2). We also examined two complementary research questions for which the prior literature did not warrant clear predictions: we explored to what extent having more ingroup friends predicts individuals' outgroup attitudes, and to what extent outgroup friends' attitudes predict individuals' outgroup attitudes.

Although the prior literature did not warrant predictions for the effects of ingroup contact and outgroup socialization, it was statistically necessary to model these effects, in order to isolate the impact of each hypothesized effect (i.e., outgroup contact and ingroup socialization) on individuals' outgroup attitudes. For example, by controlling for the effect of outgroup friends' attitudes when examining the effect of ingroup friends' attitudes, we thereby capture socialization through ingroup friends, irrespective of any other friends. Otherwise, the effect identified could reflect a mixture of ingroup and outgroup socialization. 
To provide an indication of the most likely direction of the effects, we concurrently controlled for friendship selection processes (i.e., the extent to which individuals' attitudes influence whom they select as friends). Individuals with more positive outgroup attitudes are more likely to befriend outgroup members (Binder et al., 2009; Shelton \& Richeson, 2006). Therefore, we tested whether having ingroup and outgroup friends longitudinally predicts individuals' attitudes (contact effects) while controlling for the effect of individuals' attitudes on their tendencies to befriend ingroup or outgroup members (selection effects). Additionally, individuals select as friends those who are similar in terms of various characteristics including attitudes (McPherson et al., 2001). Accordingly, we tested whether friends' attitudes longitudinally predict individuals' attitudes (socialization effects) while controlling for individuals' tendencies to befriend others with more similar attitudes (selection effects). Our research thus disentangled contact, socialization and selection effects by analyzing five waves of data, collected over one year, using longitudinal social network analysis.

Finally, we explored a potential mechanism that could link the effects of contact and socialization: extended contact. The extended contact hypothesis (Wright et al., 1997) proposes that knowledge that other ingroup members have outgroup friends, termed extended contact, can improve individuals' outgroup attitudes (Zhou et al., 2019). Theoretically, attitude socialization through ingroup friends could mediate the effect of extended contact on outgroup attitudes. That is, ingroup friends' outgroup contact (i.e., extended contact) could improve ingroup friends' outgroup attitudes, which in turn influence individuals' outgroup attitudes through the process of socialization. In the present study, we tested for this potential mediation effect in supplementary analyses. 


\section{Method}

The present research forms part of a wider investigation of intergroup relations among school students. Here, we only report measures relevant to our hypotheses. The full questionnaire is available in the Online Appendices on OSF (https://osf.io/4n9as/), where we also provide additional information about our method and analyses.

\section{Participants and Procedure}

We investigated our research questions among adolescents attending two ethnically heterogeneous schools in a town in North West England. The town has a population of $77 \%$ White and 19\% Asian (South Asian of predominantly Pakistani and Bangladeshi heritage) residents (Office for National Statistics, 2011), a history of conflictual intergroup relations (Cantle, 2005), and persistent ethnic segregation (Al Ramiah et al., 2015). We conducted the study in two of the schools in the town (for details regarding school selection and recruitment, see Online Appendix G). The two schools each contained sizeable numbers of students from the White and Asian communities (School 1: 16\% White, 82\% Asian; School 2: $39 \%$ White, $55 \%$ Asian).

We collected five waves of data over the academic year 2017/2018 (in October, December, February, March and May). The intervals between waves ranged from six to eight weeks, which corresponds to one wave per half-term in the UK school system. Collecting five waves of data over one academic year enabled us to capture the highly dynamic nature of adolescent friendship networks (Poulin \& Chan, 2010) and examine how friendships and outgroup attitudes gradually co-evolve over time.

All students in 6th (aged 11-12), 7th (aged 12-13) and 8th (aged 13-14) grades (corresponding to UK 'year groups' 7,8 and 9) were invited to participate in the study. Of a total of 1,445 students enrolled across the three grades, 1,328 (92\%) participated in at least 
one wave of data collection. Of these, we excluded 158 students who did not report their ethnicity $(n=113)$, reported an ethnicity other than Asian or White $(n=40$ Black/Black British; $n=1$ Chinese/Chinese British), or reported different ethnicities across waves $(n=4)$. This left a final sample of 1,170 students $\left(M_{a g e}=12.11, S D=0.89\right)$ of whom 829 were Asian (387 boys, 442 girls) and 341 were White (171 boys, 170 girls).

Of the final sample, $84 \%$ participated in Wave $1,81 \%$ in Wave $2,80 \%$ in Wave 3 , $79 \%$ in Wave 4, and $77 \%$ in Wave 5. For each wave, we examined whether drop-out correlated with participant attributes measured at the preceding wave. Participant attributes were, at most, weakly correlated (mean absolute $|r|=.061$ ) with participation in the subsequent wave. The proportion of non-participating students was well within the limits for social network analysis (Huisman \& Steglich, 2008).

Two weeks before the study, parents of all students received information sheets and opt-out consent forms. Less than $1 \%$ of parents indicated that they did not want their child to participate. In addition, students filled in informed consent forms at each wave of data collection. The study was approved by the University of Oxford Medical Sciences Interdivisional Research Ethics Committee (R52944/RE001).

At each wave, students completed paper-and-pencil questionnaires in classrooms during school hours. Each data collection session lasted 30 to 50 minutes. A team of two to four researchers visited each classroom to explain the study and answer any questions. Each questionnaire contained the measures described below, as well as an information sheet explaining that their participation was voluntary and their confidentiality would be maintained. 


\section{Measures}

Students completed a network measure of friendship, using self-reported friendship nominations, and self-report measures of ethnicity, attitudes towards Asian people and attitudes towards White people. To avoid well-documented response biases (Smith, 2002), we assessed the students' friendships (without reference to group memberships) before the other measures (which referred to group memberships). All measures were included at each wave.

\section{Friendship Nominations}

Friendship networks within each grade were elicited using peer-nomination procedures. Students nominated up to 10 friends in response to the question, "Who are your friends (in your year group)?”. We used grade (i.e., year group) rather than classroom network boundaries, which defined six friendship networks: grades 6,7 and 8 at each of the two schools. Students were nested in 68 classes, across six grades, in two schools. Grade is a meaningful group in the two schools, because students belong to only one grade and attend classes with only same-grade peers. Class is not a meaningful group in the two schools, because students are allocated to different classes for different subjects and thus belong to multiple cross-cutting class groups. Using grade rather than classroom network boundaries resulted in larger networks, which are well-suited for estimating the complex models required to test our hypotheses.

The six friendship networks are shown in Figure 2. The networks ranged in size from $n=163$ to $n=221$ students. On average, students nominated seven friends $(M=7.12, S D=$ 2.03), and only $4 \%$ of students consistently nominated the maximum number of 10 friends, indicating no ceiling effect. Ingroup and outgroup friendships were identified based on the correspondence between individuals' self-reported ethnicity and their friends' self-reported

ethnicity. ${ }^{1}$ Previous studies examining the associations between friendships and attitudes 
have used similar friendship measures capped at 10 nominations (e.g., Hjerm et al., 2018;

Wölfer et al., 2017). For details regarding the matching of friendship nominations, see Online Appendix G. Less than $1 \%$ of friendship nominations were unmatchable. 


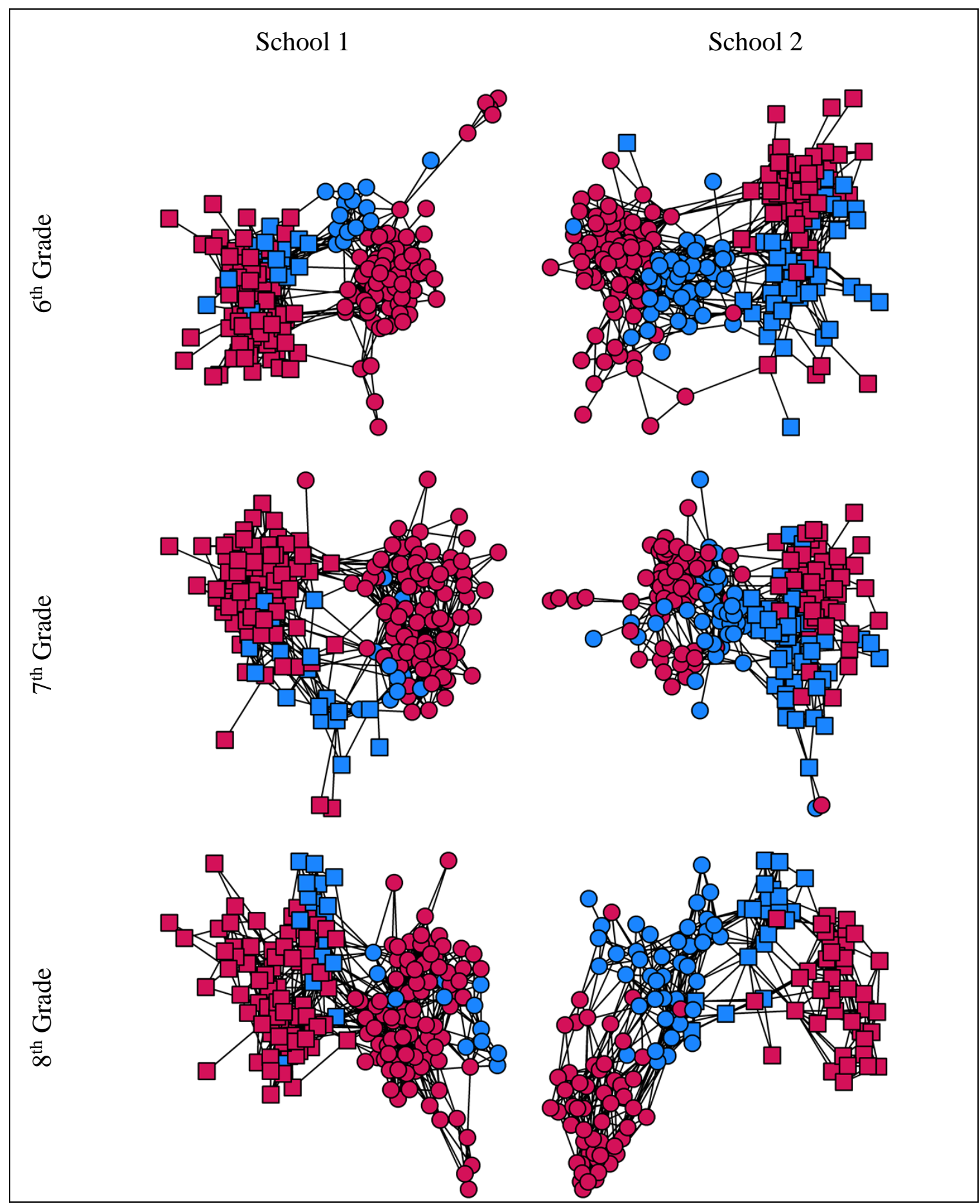

Figure 2. Friendship networks. Each node (square or circle) represents a student and each tie (link between nodes) represents a friendship. Red = Asian student; Blue $=$ White student; Square $=$ boy; Circle $=$ girl. The figure shows each friendship network at Wave 1 , with isolates removed. The networks show high levels of segregation by both ethnicity and gender. The networks are visualized using the igraph package in $\mathrm{R}$, and the coordinates of each node in the network plot are determined using the default force-directed Fruchterman-Reingold layout algorithm (Csárdi et al., 2016). 


\section{Demographic Information}

The schools provided information about students' age and gender, while students reported their own ethnicity. Students were asked, "Which of the following ethnic groups do you think best describes you?", and responded by selecting one of ten options. The sample included only students who selected either Asian or White.

\section{Attitudes}

We measured attitudes towards Asian people and White people using two identical items: "Please tell us how you feel about each of the following ethnic groups using the scales below: a) White people, b) Asian people" (1 = Very Cold, 5 = Very Warm $)$.

\section{Analysis Strategy}

To test our hypotheses, we examined the co-evolution of friendship networks and outgroup attitudes using stochastic actor-oriented models (Snijders et al., 2010) implemented in RSiena (Ripley et al., 2019). RSiena co-evolution models use simulation methods to determine how the network and individuals' attributes change over time, given specific effects that are predicted to influence change. This analysis method is unique in being able to simultaneously model the development of friendship networks and attitudes. Only by estimating all effects in one model could we investigate whether contact and socialization effects longitudinally predict attitudes, and whether attitudes longitudinally predict friendship choices (selection effects). We examined sociocentric networks, which consider the relationships (i.e., friendships) between all individuals in a given context (i.e., school grade). The resulting nonindependence of data points, both within and across networks, is controlled for in RSiena coevolution modelling.

RSiena co-evolution models consist of two types of components, which are termed "behavioral dynamics" and "network dynamics" (Steglich et al., 2006). ${ }^{2}$ The behavioral 
dynamics models attitude development and enables us to test contact and socialization effects. The estimated effects can be considered as multinomial logistic regression coefficients for ordered dependent outcomes, indicating to what extent each effect predicts changes in attitudes over time. The network dynamics models friendship choices and enables us to test selection effects. The estimated effects can be interpreted as categorical logistic regression coefficients for binary outcomes, indicating to what extent each effect predicts whom students form and maintain friendships with. For example, a same-ethnicity effect with an estimate of 1.5 represents the initial log-odds ratio that indicates that individuals are $\mathrm{e}^{1.5}=$ 4.5 times more likely to befriend an ingroup member rather than an outgroup member. In both the behavioral and network dynamics, the estimates represent the average time $\mathrm{x}$ on time $x+1$ effects across the five waves.

As this study examines the development of outgroup attitudes for both Asian and White students, we simultaneously modelled two behavioral dynamics components: attitudes towards Asian people (outgroup attitudes for White students) and attitudes towards White people (outgroup attitudes for Asian students). Accordingly, we estimated separate effects for Asian and White students. Furthermore, as we hypothesized divergent effects for ingroup and outgroup friends, we estimated separate effects for ingroup and outgroup friends. In this way, our novel model specification enabled us to examine group-dependent effects on outgroup attitudes. $^{3}$

The following subsections summarize the effects included in our models. Table A1 in the Appendix provides explanations of, and the RSiena terminology for, these effects. We provide further details of our analyses in the Online Appendices (https://osf.io/4n9as/). See Online Appendix A for further information regarding the model specification and model assumptions, and see Online Appendix B for the corresponding R script. We provide only a 
brief outline of RSiena co-evolution modelling relevant to the present study, and refer readers to prior work (e.g., Snijders et al., 2007; Steglich et al., 2006) for a more detailed overview.

\section{Behavioral Dynamics}

We simultaneously modelled attitudes towards Asian people and attitudes towards White people. The following identical sets of effects were included in these two components.

We included two contact effects. To test Hypothesis 1, we included the effect of number of outgroup friends on outgroup attitudes, which tested whether individuals with more outgroup friends developed more positive attitudes than individuals with fewer outgroup friends over time. We also included the effect of number of ingroup friends on outgroup attitudes, which tested whether individuals with more ingroup friends developed more positive or negative attitudes than individuals with fewer ingroup friends over time.

Next, we included two socialization effects. To test Hypothesis 2, we included the effect of ingroup friends' attitudes on individuals' attitudes, which tested whether individuals' attitudes became more similar to their ingroup friends' attitudes over time. We also included the effect of outgroup friends' attitudes on individuals' attitudes, which tested whether individuals' attitudes became more similar to their outgroup friends' attitudes over time.

Finally, we included five control variables: the linear and quadratic shape effects (which reflect overall changes in attitudes with time), the effect of attitudes towards White (Asian) people on attitudes towards Asian (White) people, and the main effects of ethnicity and gender. 


\section{Network Dynamics}

To obtain accurate estimates of our hypothesized effects, we controlled for confounding friendship selection processes in the network dynamics. Firstly, we controlled for the potential influences of outgroup attitudes on friendship choices (selection effects), using two types of effects. The ego attitude effect captures the influence of individuals' attitudes on the number of friendship nominations sent to ingroup and outgroup peers. The attitude similarity effect reflects to what extent individuals befriend ingroup and outgroup peers with similar attitudes to themselves.

Secondly, we included six effects controlling for demographic variables known to influence network structure: ethnic and gender differences in the number of friendship nominations sent (ego effect) and received (alter effect), and the well-documented homophilous preferences for same-ethnic and same-gender friends (McPherson et al., 2001).

Finally, we controlled for structural effects, which capture how the network itself influences friendship choices. ${ }^{4}$ For example, we included the reciprocity effect, which reflects individuals' tendencies to reciprocate friendships. Based on iterative goodness-of-fit tests and recommended practice (Ripley et al., 2019), we included twelve structural effects, which are described in Table A1 in the Appendix.

\section{Modelling Approach}

We estimated two RSiena co-evolution models. Model 1 examined contact effects on attitudes, in line with previous intergroup contact research (testing Hypothesis 1). Model 2 included all effects estimated in Model 1, but also estimated socialization effects (testing Hypotheses 1 and 2). Conducting our analysis in two steps allowed us to determine whether the contact effects documented in prior research hold before and after accounting for socialization effects. 
In each model, we combined the grade networks using the RSiena multi-group option. Using a multi-group approach enabled us to account for the nested data structure. This approach also resulted in a larger sample that provided sufficient statistical power to estimate our complex model specification. ${ }^{5}$ Missing data were treated using model-based imputation (Huisman \& Steglich, 2008; Zandberg \& Huisman, 2019).

To determine whether our models provided reliable results, we assessed convergence and goodness-of-fit. Well-estimated models produce overall maximum convergence ratios smaller than 0.25 (Ripley et al., 2019). Both Model 1 and Model 2 showed good convergence, with overall maximum convergence ratios of 0.20 and 0.19 respectively. To determine whether our models fitted the data, we calculated goodness-of-fit tests, which compared the observed and simulated data with respect to five auxiliary statistics (Lospinoso \& Snijders, 2019). The results, shown in Online Appendix C, revealed that both models adequately fitted the data.

\section{Results}

\section{Descriptives}

Table 1 shows, for each wave, the means and standard deviations for all study variables. Paired samples $t$-tests conducted at each wave indicated that both Asian and White students nominated significantly more ingroup than outgroup friends $(\Delta M>3.34, p<.001, d>0.94)$ and held significantly more positive ingroup than outgroup attitudes $(\Delta M>0.43, p<.001, d$ $>0.50$ ). The particularly substantial difference between numbers of ingroup and outgroup friends reflects a high level of ethnic segregation in the networks. The high level of ethnic segregation was similar across all six networks, as shown above in Figure 2.

Correlations between measures across waves are shown in Online Appendix D. Each individual measure was significantly correlated between waves (mean absolute $|r|=.59, p<$ 
.001). The moderate degree of stability across waves in each measure indicated sufficient change over time to model the co-development of friendships and attitudes. Furthermore, the Jaccard index (which calculates stability in the network as the similarity of friendship ties between waves) ranged from 0.34 to 0.52 , which indicates a suitable balance between network stability and change for RSiena co-evolution modelling (Ripley et al., 2019).

Table 1. Means and Standard Deviations of Friends and Attitudes by Ethnic Group

\begin{tabular}{cccccc}
\hline & Wave 1 & Wave 2 & Wave 3 & Wave 4 & Wave 5 \\
\hline Asian students $(N=829)$ & & & & & \\
Number of ingroup friends & $6.53(2.50)$ & $6.67(2.41)$ & $6.75(2.44)$ & $6.78(2.41)$ & $6.86(2.37)$ \\
Number of outgroup friends & $0.82(1.30)$ & $0.84(1.26)$ & $0.84(1.33)$ & $0.83(1.29)$ & $0.74(1.22)$ \\
Attitudes towards White people & $3.62(0.88)$ & $3.76(0.83)$ & $3.74(0.78)$ & $3.71(0.82)$ & $3.77(0.79)$ \\
Attitudes towards Asian people & $4.16(0.85)$ & $4.31(0.72)$ & $4.27(0.73)$ & $4.26(0.73)$ & $4.27(0.74)$ \\
White students $(N=341)$ & & & & & \\
Number of ingroup friends & $5.40(2.40)$ & $5.08(2.44)$ & $5.02(2.55)$ & $5.07(2.42)$ & $4.92(2.24)$ \\
Number of outgroup friends & $1.21(1.67)$ & $1.48(1.82)$ & $1.40(1.77)$ & $1.56(2.00)$ & $1.58(1.86)$ \\
Attitudes towards White people & $4.18(0.85)$ & $4.19(0.83)$ & $4.16(0.85)$ & $4.25(0.77)$ & $4.11(0.88)$ \\
Attitudes towards Asian people & $3.64(0.93)$ & $3.55(0.97)$ & $3.57(0.93)$ & $3.68(0.90)$ & $3.68(0.87)$ \\
\hline
\end{tabular}

Note. Standard deviations are shown in parentheses. Number of friends refers to outgoing friendship nominations.

\section{Behavioral Dynamics}

Table 2 shows the results for the behavioral dynamics. The estimates (log-odds ratios) represent the likelihood that an individual's outgroup attitude will become more positive or negative (as compared to not changing) based on each respective effect. Positive estimates indicate that attitudes are likely to become more positive at higher levels of the predictor, and 
negative estimates indicate that attitudes are likely to become more negative at higher levels of the predictor.

We tested contact effects in both models. Hypothesis 1 stated that having more outgroup friends would positively predict individuals' outgroup attitudes over time. The results from Model 1 provided initial support for this hypothesis. Students with more outgroup friends developed more positive outgroup attitudes than students with fewer outgroup friends (the positive estimate for the number of outgroup friends was significant for Asian students, and marginally significant for White students). However, when we additionally accounted for socialization effects in Model 2, students' number of outgroup friends no longer predicted outgroup attitudes (both estimates became non-significant). We also explored to what extent having more ingroup friends predicted individuals' outgroup attitudes. Students' number of ingroup friends did not predict outgroup attitudes (the estimates for number of ingroup friends were non-significant for both Asian and White students in Models 1 and 2).

We tested socialization effects in Model 2. Hypothesis 2 stated that ingroup friends' attitudes would predict individuals' outgroup attitudes such that their attitudes become more similar over time. The results for both Asian and White students supported this hypothesis. Students' attitudes became more similar to their ingroup friends' attitudes over time (the positive estimates for ingroup friends' attitudes were significant). We also explored to what extent outgroup friends' attitudes predicted individuals' outgroup attitudes. Students' attitudes did not become more similar to their outgroup friends' attitudes (the estimates for outgroup friends' attitudes were non-significant). Therefore, ingroup (but not outgroup) friends' attitudes predicted changes in students' outgroup attitudes. Importantly, we identified these effects while controlling for the possible tendency to select friends with similar attitudes. 
Models 1 and 2 produced similar estimates for the control effects. The significant negative estimates for the quadratic shape effects indicate that students tended not to develop more extreme attitudes over time. Additionally, the positive ethnicity effect in the Asian attitude dynamics indicates that Asian students tended towards more positive attitudes than White students. No other control effects were significant. 
Table 2. Multi-Group RSiena Co-Evolution Models: Behavioral Dynamics

\begin{tabular}{ccccccc}
\hline & \multicolumn{3}{c}{ Model 1 } & \multicolumn{3}{c}{ Model 2 } \\
\cline { 2 - 7 } & Estimate & $S E$ & $p$ & Estimate & $S E$ & $p$
\end{tabular}

White attitude dynamics

Controls

$\begin{array}{lrrrrrr}\text { Linear shape } & -0.304 & 0.161 & .059 & -0.125 & 0.159 & .433 \\ \text { Quadratic shape } & -0.475 & 0.037 & <.001 & -0.235 & 0.060 & <.001 \\ \text { Ethnicity } & -0.320 & 0.347 & .356 & -0.294 & 0.310 & .343 \\ \text { Gender } & 0.000 & 0.065 & .994 & -0.023 & 0.064 & .715 \\ \text { Attitude towards Asian people } & 0.074 & 0.064 & .250 & 0.084 & 0.064 & .188\end{array}$

Asian students (outgroup attitudes)

Number of ingroup friends

$\begin{array}{cccccc}0.043 & 0.024 & .066 & 0.024 & 0.024 & .315 \\ 0.145 & 0.049 & .003 & 0.078 & 0.077 & .308 \\ & & & 0.433 & 0.097 & <.001 \\ & & & 0.761 & 1.150 & .508\end{array}$

Asian attitude dynamics

\section{Controls}

$\begin{array}{lcccccc}\text { Linear shape } & -0.112 & 0.156 & .473 & 0.089 & 0.168 & .596 \\ \text { Quadratic shape } & -0.340 & 0.035 & <.001 & -0.152 & 0.062 & .014 \\ \text { Ethnicity } & 0.742 & 0.291 & .011 & 0.568 & 0.287 & .048 \\ \text { Gender } & -0.059 & 0.063 & .346 & -0.084 & 0.074 & .257 \\ \text { Attitude towards White people } & 0.120 & 0.064 & .064 & 0.134 & 0.070 & .055 \\ \text { ite students (outgroup attitudes) } & & & & & & \\ \text { Number of ingroup friends } & 0.045 & 0.032 & .159 & 0.018 & 0.034 & .585 \\ \text { Number of outgroup friends } & 0.098 & 0.053 & .066 & 0.185 & 0.153 & .227 \\ \text { Ingroup friends' attitudes } & & & & 0.597 & 0.213 & .005 \\ \text { Outgroup friends' attitudes } & & & & -0.999 & 1.213 & .410\end{array}$

Note. The behavioral dynamics models attitudes towards Asian people and attitudes towards White people. Model 1 tests contact effects and the corresponding selection effects. Model 2 tests contact effects, socialization effects, and the corresponding selection effects. Models include the network dynamics shown in Table 3. Models include the effects for ingroup attitudes and structural effects shown in Online Appendix A. $S E=$ standard error. $N=1170$. Ethnicity coded as $1=$ White, $2=$ Asian. Gender coded as $1=$ Boy, $2=$ Girl. 


\section{Network Dynamics}

Table 3 shows the results for the network dynamics (which were simultaneously estimated with the behavioral dynamics, but are presented separately to improve readability). The estimates (log-odds ratios) represent the likelihood that an individual will form or maintain a friendship tie based on each respective effect. Positive estimates indicate a higher likelihood of friendship, and negative estimates indicate a lower likelihood of friendship.

We controlled for the potential effects of outgroup attitudes on friendship selection (selection effects). As expected, students with more positive outgroup attitudes befriended more outgroup members over time (indicated by the positive interactions between ego attitude and outgroup friends). Unexpectedly, the estimates additionally showed that Asian students with more positive outgroup attitudes befriended more ingroup members. We also tested whether individuals befriended ingroup and outgroup members with similar attitudes to themselves. We found that attitude similarity did not predict friendship selection (indicated by the non-significant estimates for ingroup and outgroup friends' attitude similarity).

Regarding the demographic effects, the positive estimates for same-ethnicity and same-gender effects indicate that friendships were more likely between students of the same ethnicity or gender. Additionally, we found that White students received more friendship nominations than Asian students (negative alter ethnicity effect), and girls sent more friendship nominations than boys (positive ego gender effect). The twelve structural control effects followed the pattern expected based on previous research (see Online Appendix A). 
Table 3. Multi-Group RSiena Co-Evolution Models: Network Dynamics

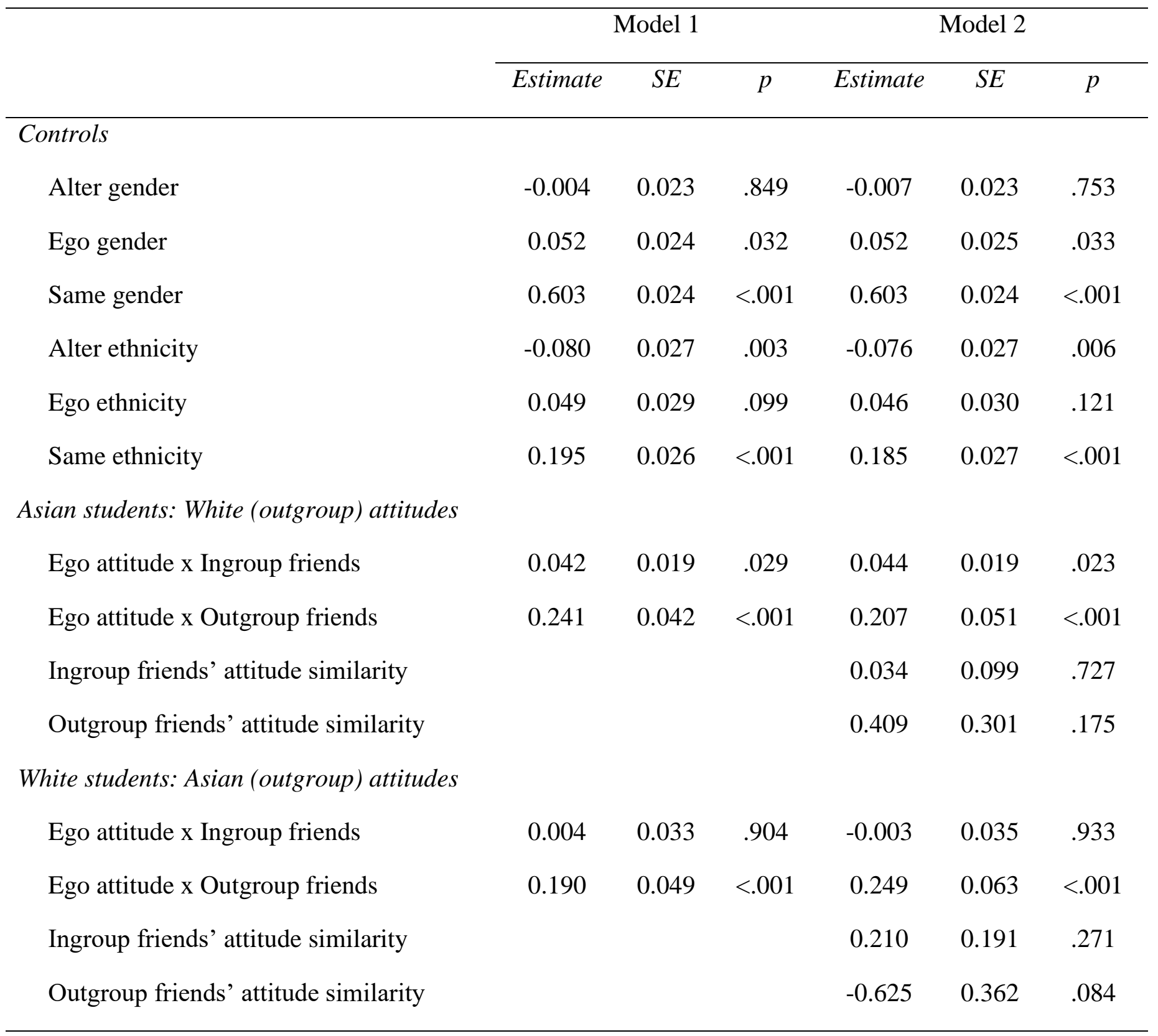

Note. The network dynamics models friendship choices. Model 1 tests contact effects and the corresponding selection effects. Model 2 tests contact effects, socialization effects, and the corresponding selection effects. Models include the behavioral dynamics shown in Table 2. Models include the effects for ingroup attitudes and structural effects shown in Online Appendix A. $S E=$ standard error. $N=1170$. Ethnicity coded as $1=$ White, $2=$ Asian. Gender coded as $1=$ Boy, $2=$ Girl. 


\section{Robustness Checks and Additional Analyses}

To verify that our findings were robust across alternative model specifications, we conducted five robustness checks. First, we re-ran the analyses without including discretionary control effects (gender, ethnicity and attitudes) in the behavioral dynamics. Second, we re-ran the analyses including only fundamental structural effects (specified in Ripley et al., 2019) in the network dynamics. Third, we re-ran the analyses with an alternative specification of attitude socialization (average attitude similarity, instead of total attitude similarity). Fourth, we reran the analyses modelling ingroup bias (i.e., the difference in attitudes towards the ingroup and outgroup) in the behavioral dynamics. Finally, we re-ran the analyses separately for Asian and White students. These five analyses are shown in Online Appendix E. The robustness checks produced highly similar results to our main analysis, increasing confidence in our findings.

We also conducted supplementary analyses to explore potential links between extended contact (i.e., knowledge of other ingroup members' outgroup friends), contact and socialization. Attitude socialization through ingroup friends could mediate the effect of extended contact on outgroup attitudes. That is, ingroup friends' outgroup contact (extended contact) could improve those ingroup friends' outgroup attitudes, which in turn predict individuals' outgroup attitudes through socialization. We tested this potential mediation in supplementary analyses, reported in Online Appendix H. Our results did not, however, provide any evidence of mediation, suggesting that attitude socialization does not mediate the effect of extended contact on outgroup attitudes (for details, see Online Appendix H). 


\section{Discussion}

The purpose of this study was to integrate, both theoretically and empirically, two wellestablished yet isolated research perspectives (intergroup contact and socialization) in order to better understand how friendships shape outgroup attitudes. We used an innovative analytic approach (longitudinal social network analysis) to address a novel theoretical issue, namely whether we could disentangle four possible effects of friendships on outgroup attitudes: the numbers of an individual's ingroup and outgroup friends (contact effects) and the attitudes held by these respective friends (socialization effects). Our results provide important insights into the divergent ways in which ingroup and outgroup friendships may shape outgroup attitudes. While we found evidence of both outgroup contact and ingroup socialization effects, we identified ingroup socialization as the most important predictor of individuals' outgroup attitudes.

When examining contact effects in isolation, we found that having more outgroup friends predicted more positive outgroup attitudes over time, in accordance with Hypothesis 1. However, when simultaneously examining contact and socialization effects, we found, in contrast to Hypothesis 1, no significant effect for outgroup contact. In all analyses, we found that having more ingroup friends did not predict outgroup attitudes. When examining socialization effects, we found that individuals' attitudes became more similar to their ingroup friends' attitudes over time, in accordance with Hypothesis 2. In all analyses, we found that outgroup friends' attitudes did not predict individuals' outgroup attitudes.

Together, these findings demonstrate the value of disentangling group-dependent contact and socialization effects in order to explore how friendships may shape outgroup attitudes. In the following sections, we discuss theoretical and practical implications of our findings and highlight the strengths and limitations of our research. 


\section{How Friends Influence Individuals' Outgroup Attitudes}

An extensive body of research examining intergroup contact theory (Allport, 1954; Brown \& Hewstone, 2005) indicates that having more outgroup friends improves outgroup attitudes (Davies et al., 2011). In the present study, we went beyond this well-established idea, to ask whether individuals' outgroup attitudes may be shaped not only by having outgroup friends, but also by their friends' attitudes (i.e., socialization). We found that having more outgroup friends predicts more positive outgroup attitudes when examined in isolation, but not when accounting for attitude socialization. Rather than contradict previous findings, however, the present research demonstrates the importance of considering multiple ways in which friendships, with both ingroup and outgroup members, may influence outgroup attitudes.

Our findings suggest that, when examining friendship more broadly, the number of outgroup friends may not always be the most important determinant of outgroup attitudes, despite having been a focus of research on intergroup contact. Instead, our findings show that individuals' outgroup attitudes were most strongly predicted by the attitudes of their ingroup friends. Prior research has shown that friends' attitudes predict individuals' attitudes towards groups (e.g., Van Zalk et al., 2013). The present findings qualify and expand upon this; in the case of examining outgroup attitudes, we found that only ingroup friends' attitudes (towards the outgroup), and not outgroup friends' attitudes (towards the same target group, their ingroup), predicted individuals' attitudes. This finding is consistent with theoretical and empirical work positing that individuals are influenced by similar others (Festinger, 1954) and the groups with which they identify (Abrams et al., 1990). Importantly, our findings revealed no effect for the number of ingroup friends on outgroup attitudes; therefore, ingroup friends seem to influence individuals' outgroup attitudes only through attitude socialization. 
To provide an indication of the direction of the observed effects, we also examined whether outgroup attitudes predict friendship selection. Results showed that individuals with more positive outgroup attitudes befriended more outgroup members, in accordance with prior research (e.g., Binder et al., 2009). In contrast to prior research (e.g., Van Zalk et al., 2013), however, we found that attitude similarity did not predict friendship selection.

Notably, this finding suggests that attitude similarity among ingroup friends occurs because individuals adopt the attitudes of their friends (socialization) and not because they select friends with similar attitudes (selection).

Together, our findings indicate that intergroup contact theory and socialization theory should be integrated in order to better understand how friendships shape outgroup attitudes. Research to date has examined either contact effects (e.g., Levin et al., 2003) or socialization effects (e.g., Van Zalk et al., 2013), but these effects have to be investigated simultaneously in order to disentangle them. By doing this in a unique manner we could, for the first time, compare the theoretical predictions from the two perspectives of intergroup contact and socialization, and we found stronger evidence of attitude socialization through ingroup friends than intergroup contact via outgroup friends. This demonstrates the importance of focusing on the ways in which friendships shape outgroup attitudes, in addition to the number of friendships.

\section{Societal and Practical Implications}

These findings have important implications for the spread of prejudice in contemporary society. With increasing ethnic diversity individuals have more opportunities to inform their outgroup attitudes through interactions with outgroup members (Schmid et al., 2014). However, our findings showed high levels of ethnic segregation in friendship networks, indicating that individuals were seldom choosing to avail themselves of the opportunities for 
outgroup contact available in their diverse schools. If individuals interact predominantly with ingroup members, and are influenced primarily by each other's outgroup attitudes, this may increase the spread of potentially uninformed or biased outgroup attitudes based on ingroup perceptions of the outgroup rather than experiences with the outgroup. This may also lead to group polarization, as individuals' outgroup attitudes become more extreme through group discussion (Moscovici \& Zavalloni, 1969).

It is important to consider the context in which we demonstrated these effects. Our sample consisted of high school students from an ethnically diverse town. The multi-ethnic and multi-religious school setting is an increasingly typical environment in which adolescents grow up. This town has a history of interethnic conflict, and persistent residential and educational segregation (Al Ramiah et al., 2015). Accordingly, we examined the development of outgroup attitudes in a challenging intergroup climate, which is an important context in which to examine, and consequently better understand, intergroup relations (Hewstone et al., 2014). The ethnically diverse context also enabled us to examine the development of outgroup attitudes for both the traditionally advantaged majority group and the, often neglected, disadvantaged minority group (see Wölfer et al., 2016). Together, the diversity of the sample and real life setting provide external validity.

However, outgroup attitudes may develop differently depending on the intergroup context. In environments where the intergroup climate is negative, individuals may be less inclined to interact with outgroup members, and more inclined to rely on ingroup members to inform their attitudes towards outgroups. Therefore, the intergroup context may account for differences in the findings of our study and previous studies examining intergroup contact theory: outgroup contact effects may be stronger in more integrated harmonious environments, and weaker in more segregated hostile environments. Future research should 
therefore make use of our innovative approach to study how the effects of ingroup and outgroup friendships differ across a range of environments.

Furthermore, in the context of the schools in the present study, Asian students comprised the numerical majority group and White students comprised the numerical minority group. This demography is reversed in the town and UK more broadly, and White and Asian groups are, respectively, majority and minority ethnic groups in terms of status. The complexity of the intergroup context may have impacted the findings. For example, ingroup socialization effects may be more pronounced for groups with a consistent minority status, because shared outgroup attitudes may be particularly important for minority as compared to majority groups (Garcia et al., 2017). Conversely, outgroup contact effects may be more pronounced for groups with a consistent ethnic majority status (Tropp \& Pettigrew, 2005). Future research should explore potential differences in the findings depending on contextual group characteristics, including majority-minority status. More broadly, future research should also explore differences across alternative group dimensions (e.g., socioeconomic status).

Our findings could inform the design of social interventions aimed at improving intergroup relations in schools. Typical intervention programs target large groups such as entire classrooms (e.g., Houlette et al., 2004; Stathi et al., 2014), which are complex and expensive. More recently, network interventions have been implemented, which improve the attitudes of a small subset of individuals within the network, who subsequently influence the attitudes of their peers in the wider network (Paluck, 2011; Paluck et al., 2016). By targeting only a subset of students, network interventions are more efficient and effective (Valente, 2012). To further increase effectiveness, it is important to identify which individuals to target (Zingora et al., 2019). As interventions aim to reduce prejudice and discrimination from the advantaged majority group towards disadvantaged minority groups, the present findings 
suggest that interventions could target a subset of the majority group. Because attitude socialization occurs through ingroup, not outgroup, members, these individuals are more likely to subsequently influence the wider majority group.

Importantly, attitude socialization in and of itself is unlikely to improve intergroup relations. Positive attitudes must first be developed among certain individuals, in order for these attitudes to subsequently spread through socialization. Prior research suggests that outgroup friendship is a specific form of intergroup contact that provides a well-substantiated means of improving individuals' outgroup attitudes (Davies et al., 2011), and this improvement could have a wider impact on other ingroup members through subsequent attitude socialization. Therefore, combined interventions that promote both outgroup friendship (to improve outgroup attitudes) and 'targeted' ingroup friendship (with ingroup members holding more positive attitudes, which may then spread through socialization) may be a promising dual-pronged approach to investigate.

This approach highlights how ingroup socialization effects are indirectly related to outgroup contact: the attitudes of one's ingroup friends may be driven, in part, by those friends' own outgroup contact experiences. Furthermore, this approach draws upon the extended contact hypothesis (Wright et al., 1997), which states that extended contact (i.e., knowledge of other ingroup members' outgroup friends) can improve individuals' outgroup attitudes. Theoretically, attitude socialization could mediate the effect of extended contact on outgroup attitudes. That is, ingroup friends' outgroup contact (extended contact) could improve those ingroup friends' outgroup attitudes, which in turn influence individuals' outgroup attitudes through the process of socialization. The results of our supplementary analyses testing for this potential mediation effect did not, however, provide any evidence of mediation (for details, see Online Appendix H). 


\section{Strengths, Limitations and Future Directions}

The key contribution of this study is to advance our understanding of whether and, if so, how ingroup and outgroup friendships may shape outgroup attitudes. This was made possible by using state-of-the-art longitudinal social network analysis, which disentangled four potential effects on individuals' attitudes: the number of ingroup and outgroup friends (contact effects), and ingroup and outgroup friends' attitudes (socialization effects). We were further able to separate contact and socialization effects from friendship selection processes, and thus to explore directionality. This novel method should inform future research studying outgroup attitude development in friendship networks.

Longitudinal social network analysis, still rare in social psychological research, also enabled us to obtain more objective measures of outgroup friendship (Smith, 2002), and examine friendships within the social context, controlling for network structure (Snijders et al., 2010). By using a five-wave design, we were able to examine how friendships and outgroup attitudes gradually unfold in relation to each other. Furthermore, the relatively short time intervals between waves (six to eight weeks) enabled us to capture fine-grained changes in the highly dynamic friendship networks of adolescents (Poulin \& Chan, 2010).

Regarding sample size and power, we used multiple strategies to obtain a sample large enough to detect even small effects. Firstly, we recruited six grades from two schools, totalling 1,445 students, and obtained a high participation rate of $92 \%$. Secondly, we used grade rather than classroom network boundaries, which resulted in larger networks, ranging from 163 to 221 students. Finally, we combined the grade networks using the RSiena multigroup option, which allowed us to synthesize estimations from the six separate networks and control for the nested data structure. Although statistical power in data which is (by definition) built on interdependencies cannot be assessed with traditional power analysis 
methods (Ripley et al., 2019), simulation studies show that our large sample provided sufficient power. Simulation studies addressing statistical power in longitudinal network designs show that in studies with five waves, a sample size of $N \geq 120$ yields sufficient power (Stadtfeld et al., 2018).

Although the use of longitudinal social network analysis is an unequivocal strength of this study, it also has limitations. Social network analysis is restricted to a specific network boundary. We examined friendships within school grade networks. Adolescents spend most of their waking hours in school, and most adolescent friendships are formed within school environments (George \& Hartmann, 1996). Nonetheless, we miss the potentially important effects that friends outside of school and family members may have on outgroup attitude development (Miklikowska, 2017).

Furthermore, the present study did not focus on the mechanisms underlying attitude socialization through ingroup friends. Consequently, it remains unclear how ingroup friends influence each other's outgroup attitudes. Multiple mechanisms could be operating, such as modelling, peer pressure, communication, normative influence, and/or informational influence. For example, Aboud and Doyle (1996) found that individuals' outgroup attitudes could be changed through discussion with ingroup friends holding differing outgroup attitudes. Other studies have highlighted the potential role of ethnic jokes and humour in influencing friends' attitudes towards social groups (e.g., Lampert \& Ervin-Tripp, 2006; Stangor \& Leary, 2006). Future research should examine which specific mechanisms underlie attitude socialization through ingroup friends.

Future studies should also investigate alternative intergroup contexts and age groups to assess the generalizability of our findings. With regard to age, the present study focused on adolescence, which marks a key period in the development of outgroup attitudes (Aboud, 
2005; Wölfer et al., 2016). It is possible that the relative effects of contact and socialization on outgroup attitudes may differ depending on age. For example, socialization effects may be particularly pronounced during adolescence, because adolescents are especially susceptible to social influence compared with other age groups (Telzer et al., 2018). We could not consider age effects in the present study, because the sample was highly homogenous in age. To determine whether the present findings generalize across the lifespan, future research should examine how friends influence attitudes at younger ages, when attitudes originate, and at older ages, after attitudes have stabilized.

Finally, it is important to acknowledge that the present findings cannot provide unequivocal evidence of causal effects. The longitudinal design aids a better understanding of the direction of the associations between friendships and attitudes than would a crosssectional study. Moreover, RSiena co-evolution models provide insight into directionality by assessing reverse effects through the accurate estimation of friendship selection effects (Ripley et al., 2019). Nonetheless, causality cannot be inferred from RSiena co-evolution models, because this analysis technique, like many others, cannot determine whether any omitted confounding variables are correlated with what we have identified as the effects of contact and socialization (Lomi et al., 2011). Accordingly, future experimental research is required to determine whether the effects identified in the present study are causal.

\section{Conclusion}

The present research makes an original and important contribution towards understanding how ingroup and outgroup friends influence the development of outgroup attitudes. Using innovative longitudinal social network analysis, we were able to disentangle the effects of the number of ingroup and outgroup friends, and the effects of ingroup and outgroup friends' attitudes, on individuals' attitudes. In so doing, we found that the most important predictor of 
individuals' outgroup attitudes was not their number of outgroup friends, but socialization through ingroup friends (i.e., ingroup friends' attitudes). This demonstrates a potentially worrying avenue for the spread of uninformed or biased outgroup attitudes, but also presents a potentially promising avenue for interventions to target. We hope that these findings inspire future research to consider the under-examined roles of ingroup friendship and attitude socialization in outgroup attitude development.

\section{Endnotes}

${ }^{1}$ The operationalization of outgroup contact as the number of nominated outgroup friends is likely to encompass both contact quantity and quality. Friendship is conceptualized as an optimal and especially effective form of contact (Pettigrew, 1998). Furthermore, friendship generally entails most of the optimal conditions that facilitate the effects of outgroup contact (Allport, 1954), specifically cooperation, common goals, and equal status (Pettigrew, 1997). The conceptualization of friendship as high quality contact is empirically supported by a prior study conducted in one school of this sample (Van Zalk et al., in press), which measured both friendship and contact quality and identified a strong correlation between these measures at each wave (mean $|r|=.61, p<.001)$.

${ }^{2}$ In this paper we use established RSiena terminology consistent with prior literature. The term "behavioral" should not be taken literally here: the behavioral dynamics can model any attributes of individuals, including attitudes, in addition to behaviors.

${ }^{3}$ Our model specification necessitated concurrently modelling ingroup attitudes (see Online Appendix A). In line with our hypotheses, we focus on outgroup attitudes in the main text.

${ }^{4}$ Structural effects capture endogenous network mechanisms that impact friendships and, therefore, represent important confounding effects (Snijders et al., 2007). The exclusion of 
structural effects can lead to biases in the estimates for other effects, including those used in testing the hypotheses. Descriptions of the structural effects included in the present analyses are provided in Table A1 in the Appendix. We included four fundamental structural effects recommended for all RSiena models (Ripley et al., 2019): 'outdegree', 'reciprocity', 'gwespFF', and 'transitive reciprocated triplets'. In accordance with recommended practice, we included eight additional structural effects based on iterative goodness-of-fit testing (Lospinoso \& Snijders, 2019): 'gwespBB', 'three-cycles', 'indegree popularity', 'outdegree popularity', 'outdegree activity', 'reciprocal degree popularity', 'reciprocal degree activity', and 'truncated outdegree'. The need to add these effects was empirically suggested by model fit estimation. The goodness-of-fit tests are shown in Online Appendix C. The inclusion versus exclusion of the additional structural effects only impacted goodness-of-fit, and did not impact the results relating to the hypotheses (for details, see the robustness checks in Online Appendix E).

${ }^{5}$ We were unable to attain convergence when estimating our models using the six networks individually. This precluded the use of alternative methods for analyzing multiple networks (e.g., RSiena meta-analysis). 


\section{References}

Aboud, F. E. (2005). The development of prejudice in childhood and adolescence. In J. F. Dovidio, P. Glick, \& L. A. Rudman (Eds.), On the nature of prejudice: Fifty years after Allport (pp. 310-326). Malden, MA: Blackwell Publishing.

Aboud, F. E., \& Doyle, A. B. (1996). Does talk of race foster prejudice or tolerance in children? Canadian Journal of Behavioural Science, 28, 161-170. https://doi.org/10.1037/0008-400X.28.3.161

Abrams, D., Wetherell, M., Cochrane, S., Hogg, M. A., \& Turner, J. C. (1990). Knowing what to think by knowing who you are: Self-categorization and the nature of norm formation, conformity and group polarization. British Journal of Social Psychology, 29, 97-119. https://doi.org/10.1111/j.2044-8309.1990.tb00892.x

Allport, G. W. (1954). The nature of prejudice. Reading, MA: Addison-Wesley.

Al Ramiah, A., Schmid, K., Hewstone, M., \& Floe, C. (2015). Why are all the White (Asian) kids sitting together in the cafeteria? Resegregation and the role of intergroup attributions and norms. British Journal of Social Psychology, 54, 100-124. https://doi.org/10.1111/bjso.12064

American Psychological Association. (2020). Socialization. In APA dictionary of psychology. Retrieved from https://dictionary.apa.org/socialization

Binder, J., Zagefka, H., Brown, R., Funke, F., Kessler, T., Mummendey, A., Maquil, A., Demoulin, S., \& Leyens, J. (2009). Does contact reduce prejudice or does prejudice reduce contact? A longitudinal test of the contact hypothesis among majority and minority groups in three European countries. Journal of Personality and Social Psychology, 96, 843-856. https://doi.org/10.1037/a0013470

Brown, R., \& Hewstone, M. (2005). An integrative theory of intergroup contact. Advances in Experimental Social Psychology, 37, 255-343. https://doi.org/10.1016/S00652601(05)37005-5

Bukowski, W. M., Newcomb, A. F., \& Hartup, W. W. (Eds.) (1998). The company they keep: Friendship in childhood and adolescence. Cambridge, UK: Cambridge University 
Press.

Cantle, T. (2005). Community cohesion: A new framework for race and diversity. Basingstoke, UK: Palgrave Macmillan.

Csárdi, G., Nepusz, T., \& Airoldi, E. M. (2016). Statistical network analysis with igraph. New York, NY: Springer.

Davies, K., Tropp, L. R., Aron, A., Pettigrew, T. F., \& Wright, S. C. (2011). Cross-group friendships and intergroup attitudes: A meta-analytical review. Personality and Social Psychology Review, 15, 332-351. https://doi.org/10.1177/1088868311411103

Festinger, L. (1954). A theory of social comparison processes. Human Relations, 7, 117-140. https://doi.org/10.1177/001872675400700202

Festinger, L., Schachter, S., \& Back, K. W. (1950). Social pressures in informal groups: A study of human factors in housing. New York, NY: Harper.

Garcia, R. L., Bergsieker, H. B., \& Shelton, J. N. (2017). Racial attitude (dis)similarity and liking in same-race minority interactions. Group Processes \& Intergroup Relations, 20, 501-518. https://doi.org/10.1177/1368430215612224

George, T. P., \& Hartmann, D. P. (1996). Friendship networks of unpopular, average, and popular children. Child Development, 67, 2301-2316. https://doi.org/10.2307/1131624

Hartup, W. W. (1996). The company they keep: Friendships and their developmental significance. Child Development, 67, 1-13. https://doi.org/10.1111/j.14678624.1996.tb01714.x

Hewstone, M., Lolliot, S., Swart, H., Myers, E., Voci, A., Al Ramiah, A., \& Cairns, E. (2014). Intergroup contact and intergroup conflict. Peace and Conflict: Journal of Peace Psychology, 20, 39-53. https://doi.org/10.1037/a0035582

Hjerm, M., Eger, M. A., \& Danell, R. (2018). Peer attitudes and the development of prejudice in adolescence. Socius, 4, 1-11. https://doi.org/10.1177/2378023118763187

Houlette, M. A., Gaertner, S. L., Johnson, K. M., Banker, B. S., Riek, B. M., \& Dovidio, J. F. (2004). Developing a more inclusive social identity: An elementary school 
intervention. Journal of Social Issues, 60, 35-55. https://doi.org/10.1111/j.00224537.2004.00098.x

Huisman, M., \& Steglich, C. (2008). Treatment of non-response in longitudinal network studies. Social Networks, 30, 297-308. https://doi.org/10.1016/j.socnet.2008.04.004

Joyner, K., \& Kao, G. (2000). School racial composition and adolescent racial homophily. Social Science Quarterly, 81, 810-825. https://www.jstor.org/stable/42864005

Kandel, D. B. (1978). Homophily, selection, and socialization in adolescent friendships. American Journal of Sociology, 84, 427-436. https://doi.org/10.1086/226792

Lampert, M., \& Ervin-Tripp, S. M. (2006). Risky laughter: Teasing and self-directed joking among male and female friends. Journal of Pragmatics, 38, 51-72. https://doi.org/10.1016/j.pragma.2005.06.004

la Roi, C., Dijkstra, J. K., Kretschmer, T., Savickaite, R., \& Veenstra, R. (2020). Peers and homophobic attitudes in adolescence: Examining selection and influence processes in friendships and antipathies. Journal of Youth and Adolescence, 49, 2229-2245. https://doi.org/10.1007/s10964-020-01298-8

Levin, S., Van Laar, C., \& Sidanius, J. (2003). The effects of ingroup and outgroup friendships on ethnic attitudes in college: A longitudinal study. Group Processes \& Intergroup Relations, 6, 76-92. https://doi.org/10.1177/1368430203006001013

Lomi, A., Snijders, T. A. B., Steglich, C., \& Torló, V. J. (2011). Why are some more peer than others? Evidence from a longitudinal study of social networks and individual academic performance. Social Science Research, 40, 1506-1520. https://doi.org/10.1016/j.ssresearch.2011.06.010

Lospinoso, J. A., \& Snijders, T. (2019). Goodness of fit for stochastic actor-oriented models. Methodological Innovations, 1-18. https://doi.org/10.1177/2059799119884282

MacInnis, C. C., \& Page-Gould, E. (2015). How can intergroup interaction be bad if intergroup contact is good? Exploring and reconciling an apparent paradox in the science of intergroup relations. Perspectives on Psychological Science, 10, 307-327. https://doi.org/10.1177/1745691614568482 
McGuire, L., Rutland, A., \& Nesdale, D. (2015). Peer group norms and accountability moderate the effect of school norms on children's intergroup attitudes. Child Development, 86, 1290-1297. https://doi.org/10.1111/cdev.12388

McPherson, M., Smith-Lovin, L., \& Cook, J. M. (2001). Birds of a feather: Homophily in social networks. Annual Review of Sociology, 27, 415-444. https://doi.org/10.1146/annurev.soc.27.1.415

Miklikowska, M. (2017). Development of anti-immigrant attitudes in adolescence: The role of parents, peers, intergroup friendships, and empathy. British Journal of Psychology, 108, 626-648. https://doi.org/10.1111/bjop.12236

Milgram, S. (1967). The small-world problem. Psychology Today, 1, 61-67.

Moscovici, S., \& Zavalloni, M. (1969). The group as a polarizer of attitudes. Journal of Personality and Social Psychology, 12, 125-135. https://doi.org/10.1037/h0027568

Munniksma, A., Stark, T. H., Verkuyten, M., Flache, A., \& Veenstra, R. (2013). Extended intergroup friendships within social settings: The moderating role of initial outgroup attitudes. Group Processes \& Intergroup Relations, 16, 752-770. https://doi.org/10.1177/1368430213486207

Munniksma, A., Verkuyten, M., Flache, A., Stark, T. H., \& Veenstra, R. (2015). Friendships and outgroup attitudes among ethnic minority youth: The mediating role of ethnic and host society identification. International Journal of Intercultural Relations, 44, 88-99. https://doi.org/10.1016/j.ijintrel.2014.12.002

Office for National Statistics. (2011). 2011 Census. Retrieved from https://www.ons.gov.uk/census/2011census

Paluck, E. L. (2011). Peer pressure against prejudice: A high school field experiment examining social network change. Journal of Experimental Social Psychology, 47, 350-358. https://doi.org/10.1016/j.jesp.2010.11.017

Paluck, E. L., Shepherd, H., \& Aronow, P. M. (2016). Changing climates of conflict: A social network experiment in 56 schools. Proceedings of the National Academy of Sciences, 113, 566-571. https://doi.org/10.1073/pnas.1514483113 
Pettigrew, T. F. (1997). Generalized intergroup contact effects on prejudice. Personality and Social Psychology Bulletin, 23, 173-185. https://doi.org/10.1177/0146167297232006

Pettigrew, T. F. (1998). Intergroup contact theory. Annual Review of Psychology, 49, 65-85. https://doi.org/10.1146/annurev.psych.49.1.65

Pettigrew, T. F., \& Tropp, L. R. (2006). A meta-analytic test of intergroup contact theory. Journal of Personality and Social Psychology, 90, 751-783. https://doi.org/10.1037/0022-3514.90.5.751

Poteat, V. P. (2007). Peer group socialization of homophobic attitudes and behavior during adolescence. Child Development, 78, 1830-1842. https://doi.org/10.1111/j.14678624.2007.01101.x

Poulin, F., \& Chan, A. (2010). Friendship stability and change in childhood and adolescence. Developmental Review, 30, 257-272. https://doi.org/10.1016/j.dr.2009.01.001

Ripley, R. M., Snijders, T., Boda, Z., Vörös, A., \& Preciado, P. (2019). Manual for RSiena. Retrieved from http://www.stats.ox.ac.uk/ snijders/siena/

Schmid, K., Al Ramiah, A., \& Hewstone, M. (2014). Neighborhood ethnic diversity and trust: The role of intergroup contact and perceived threat. Psychological Science, 25, 665-674. https://doi.org/10.1177/0956797613508956

Shelton, J. N., \& Richeson, J. A. (2006). Ethnic minorities' racial attitudes and contact experiences with White people. Cultural Diversity and Ethnic Minority Psychology, 12, 149-164. https://doi.org/10.1037/1099-9809.12.1.149

Smith, T. W. (2002). Measuring inter-racial friendships. Social Science Research, 31, 576593. https://doi.org/10.1016/S0049-089X(02)00015-7

Snijders, T., Steglich, C. E. G., \& Schweinberger, M. (2007). Modeling the co-evolution of networks and behavior. In K. Van Montfort, H. Oud, \& A. Satorra (Eds.), Longitudinal models in the behavioral and related sciences (pp. 41-71). Mahwah, NJ: Erlbaum.

Snijders, T., van de Bunt, G. G., \& Steglich, C. E. G. (2010). Introduction to stochastic actorbased models for network dynamics. Social Networks, 32, 44-60. 
https://doi.org/10.1016/j.socnet.2009.02.004

Stadtfeld, C., Snijders, T. A. B., Steglich, C., \& van Duijn, M. (2018) Statistical power in longitudinal network studies. Sociological Methods \& Research, 1-30. https://doi.org/10.1177/0049124118769113

Stangor, C., \& Leary, S. P. (2006). Intergroup beliefs: Investigations from the social side. Advances in Experimental Social Psychology, 38, 243-281. https://doi.org/10.1016/S0065-2601(06)38005-7

Stangor, C., Sechrist, G. B., \& Jost, J. T. (2001). Changing racial beliefs by providing consensus information. Personality and Social Psychology Bulletin, 27, 486-496. https://doi.org/10.1177/0146167201274009

Stathi, S., Cameron, L., Hartley, B., \& Bradford, S. (2014). Imagined contact as a prejudicereduction intervention in schools: The underlying role of similarity and attitudes. Journal of Applied Social Psychology, 44, 536-546. https://doi.org/10.1111/jasp.12245

Steglich, C., Snijders, T., \& West, P. (2006). Applying SIENA: An illustrative analysis of the coevolution of adolescents' friendship networks, taste in music, and alcohol consumption. Methodology, 2, 48-56. https://doi.org/10.1027/1614-2241.2.1.48

Swart, H., Hewstone, M., Christ, O., \& Voci, A. (2011a). Affective mediators of intergroup contact: A three-wave longitudinal study in South Africa. Journal of Personality and Social Psychology, 101, 1221-1238. https://doi.org/10.1037/a0024450

Swart, H., Turner, R., Hewstone, M., \& Voci, A. (2011b). Achieving outgroup forgiveness and outgroup trust: The importance of cross-group friendships, self-disclosure, and empathy. In L. R. Tropp \& R. K. Mallett (Eds.), Beyond prejudice reduction: Pathways to positive intergroup relations (pp. 181-200). Washington, DC: APA Books.

Telzer, E. H., Van Hoorn, J., Rogers, C. R., \& Do, K. T. (2018). Social influence on positive youth development: A developmental neuroscience perspective. Advances in Child Development and Behavior, 54, 215-258. https://doi.org/10.1016/bs.acdb.2017.10.003 
Thijs, J., \& Verkuyten, M. (2011). Ingroup bias in the classroom: The role of co-ethnic and other-ethnic peers and multiculturalism. Anales de Psicologia, 27, 662-669. https://doi.org/10.6018/analesps

Tropp, L. R., \& Pettigrew, T. F. (2005). Relationships between intergroup contact and prejudice among minority and majority status groups. Psychological Science, 16, 951957. https://doi.org/10.1111/j.1467-9280.2005.01643.x

Turner, J. C., Hogg, M. A., Oakes, P. J., Reicher, S. D. \& Wetherell, M. S. (1987). Rediscovering the social group: A self-categorization theory. Oxford, UK: Basil Blackwell.

United Nations. (2019). International Migrant Stock 2019. Retrieved from https://www.un.org/en/development/desa/population/migration/data/estimates2/estima tes19.asp

Valente, T. W. (2012). Network interventions. Science, 337, 49-53. https://doi.org/10.1126/science.1217330

Van Zalk, M., Kerr, M., Van Zalk, N., \& Stattin, H. (2013). Xenophobia and tolerance toward immigrants in adolescence: Cross-influence processes within friendships. Journal of Abnormal Child Psychology, 41, 627-639. https://doi.org/10.1007/s10802013-9745-9

Van Zalk, M., Kotzur, P., Schmid, K., Al Ramiah, A., \& Hewstone, M. (in press). Adolescent development of interethnic attitudes following a social intervention to increase intergroup contact: The moderating role of affective forecasting. Developmental Psychology.

Vertovec, S. (2007). Super-diversity and its implications. Ethnic and Racial Studies, 30, 1024-1054. https://doi.org/10.1080/01419870701599465

Wilder, D. A., \& Thompson, J. E. (1980). Intergroup contact with independent manipulations of in-group and out-group interaction. Journal of Personality and Social Psychology, 38, 589-603. https://doi.org/10.1037/0022-3514.38.4.589

Wölfer, R., Faber, N. S., \& Hewstone, M. (2015). Social network analysis in the science of 
groups: Cross-sectional and longitudinal applications for studying intra- and intergroup behavior. Group Dynamics: Theory, Research, and Practice, 19, 45-61. https://doi.org/10.1037/gdn0000021

Wölfer, R., \& Hewstone, M. (2017). Beyond the dyadic perspective: 10 Reasons for using social network analysis in intergroup contact research. British Journal of Social Psychology, 56, 609-617. https://doi.org/10.1111/bjso.12195

Wölfer, R., Jaspers, E., Blaylock, D., Wigoder, C. W., Hughes, J., \& Hewstone, M. (2017). Studying positive and negative direct and extended contact: Complementing selfreports with social network analysis. Personality and Social Psychology Bulletin, 43, 1566-1581. https://doi.org/10.1177/0146167217719732

Wölfer, R., Schmid, K., Hewstone, M., \& Van Zalk, M. (2016). Developmental dynamics of intergroup contact and intergroup attitudes: Long-term effects in adolescence and early adulthood. Child Development, 87, 1466-1478. https://doi.org/10.1111/cdev.12598

Wright, S. C., Aron, A., McLaughlin-Volpe, T., \& Ropp, S. A. (1997). The extended contact effect: Knowledge of cross-group friendships and prejudice. Journal of Personality and Social Psychology, 73, 73-90. https://doi.org/10.1037/0022-3514.73.1.73

Zandberg, T., \& Huisman, M. (2019). Missing behavior data in longitudinal network studies: The impact of treatment methods on estimated effect parameters in stochastic actor oriented models. Social Network Analysis and Mining, 9, 1-20. https://doi.org/10.1007/s13278-019-0553-2

Zhou, S., Page-Gould, E., Aron, A., Moyer, A., \& Hewstone, M. (2019). The extended contact hypothesis: A meta-analysis on 20 years of research. Personality and Social Psychology Review, 23, 132-160. https://doi.org/10.1177/1088868318762647

Zingora, T., Stark, T. H., \& Flache, A. (2019). Who is most influential? Adolescents' intergroup attitudes and peer influence within a social network. Group Processes \& Intergroup Relations. https://doi.org/10.1177/1368430219869460 


\section{Appendix}

Table A1. Explanation of RSiena Effects

Effect (RSiena terminology) Explanation

Behavioral dynamics

Control effects

Linear shape

(linear)

Quadratic shape

(quad)

Ethnicity

(effFrom)

Gender

(effFrom)

Attitude towards White/Asian people (effFrom)

Contact and socialization effects

Number of ingroup friends

(totWAlt)*

Number of outgroup friends

(totWAlt)*

Ingroup friends' attitudes

(totSimW)*

Outgroup friends' attitudes

(totSimW)*

Network dynamics

Demographic control effects

Alter gender

(altX)

Ego gender

(egoX)

Same gender

(sameX)

Alter ethnicity

(altX)

Ego ethnicity

(egoX)

Same ethnicity

(sameX)

Selection effects
Basic drive toward higher values on the dependent variable (attitudes)

Tendency for students with very positive or very negative attitudes to develop even more extreme attitudes

Effect of ethnicity (Asian/White) on attitudes

Effect of gender (boy/girl) on attitudes

Effect of attitudes towards White [Asian] people on attitudes towards Asian [White] people

Tendency for students with more ingroup friends to develop more positive attitudes

Tendency for students with more outgroup friends to develop more positive attitudes

Tendency for students to adopt the attitudes of their ingroup friends

Tendency for students to adopt the attitudes of their outgroup friends

Tendency for girls to receive more incoming friendship nominations than boys

Tendency for girls to send more outgoing friendship nominations than boys

Tendency to befriend those of the same gender

Tendency for Asian students to receive more incoming friendship nominations than White students

Tendency for Asian students to send more outgoing friendship nominations than White students

Tendency to befriend those of the same ethnicity 
Ego attitude $\mathrm{x}$ Ingroup friends (egoX)*

Ego attitude x Outgroup friends (egoX)*

Ingroup friends' attitude similarity

$(\operatorname{sim} X)^{*}$

Outgroup friends' attitude similarity $(\operatorname{sim} X)^{*}$

Structural control effects

Outdegree

(density)

Reciprocity

(recip)

GWESP I $\rightarrow \mathrm{K} \rightarrow \mathrm{J}$

(gwespFF)

GWESP $\mathrm{I} \leftarrow \mathrm{K} \leftarrow \mathrm{J}$

(gwespBB)

Transitive reciprocated triplets

(transRecTrip)

Three-cycles

(cycle3)

Indegree popularity

(inPopSqrt)

Outdegree popularity

(outPop)

Outdegree activity

(outAct)

Reciprocal degree popularity

(reciPop)

Reciprocal degree activity

(reciAct)

Truncated outdegree

(outTrunc 1)
Tendency for students with more positive attitudes to befriend more ingroup members

Tendency for students with more positive attitudes to befriend more outgroup members

Tendency for students to befriend ingroup members with similar attitudes to themselves

Tendency for students to befriend outgroup members with similar attitudes to themselves

Tendency to form new friendship ties

Tendency to reciprocate friendship ties

Tendency to befriend the friends of friends (transitive)

Tendency to befriend the friends of friends (cyclical)

Tendency to have reciprocated friendship ties to friends of friends

Tendency against local hierarchy

Tendency for those with many incoming nominations to receive even more incoming nominations

Tendency for those with many outgoing nominations to receive more incoming nominations

Tendency for those with many outgoing nominations to send even more outgoing nominations

Tendency for those with many reciprocal nominations to receive more incoming nominations

Tendency for those with many reciprocal nominations to send more outgoing nominations

Tendency to send no outgoing nominations

Note. Asterisks indicate dyadic covariate interations with the respective RSiena effects. The dyadic covariate interations enabled us to estimate separate effects for ingroup and outgroup friends and for Asian and White students (see Online Appendix A for further information). 